\title{
Impact of national culture in projects involving organizational culture change: Japanese Business Practices
}

\author{
Impacto da cultura nacional em projetos envolvendo mudança de cultura organizacional: Práticas \\ Japonesas de Negócios
}

Izabela Lopes ${ }^{1} \odot$; João Carlos Boyadjian² ${ }^{\oplus}$

Received: mar. 19, 2018

Accepted: nov. 10, 2020

${ }^{1}$ SSIM - Sustainable Society Investment Management. Assistant Manager, Business Development. Shibakoen ND Bldg.6F, 2-5-10 Shiba, Minato-ku, Tokyo, Japan <izabelalopes@hotmail.co.uk>

2 JCB Management, Mestre em Engenharia Naval. Av. Bagiru, 696 - Boaçava - 05469-020 - São Paul - SP - Brasil.

\begin{abstract}
Globalization exerts a significant impact on project management processes by adding the complexity to operate across borders and in multicultural environments. For that reason, international collaborations require cultural affairs to be at the center of business strategies to avoid conflicts with the host country practices. For instance, Japan has unique business practices compared to most Western countries, and those must be considered in an eventual organizational culture change. The aim was to understand the importance of working the organizational culture in international projects. Therefore, it will describe some peculiarities of Japanese business culture and how they were formed while making a parallel comparison with western business practices. An observational study of the first project of an Alliance between a Japanese multinational automobile manufacturer (JMAM) and a French multinational automobile manufacturer (FMAM) was applied to highlight the contrasts of Japanese and Western business practices. To understand the complexities of culture from different angles, this paper divided the research into different phases, each exploring the different cultural aspects of Japanese and French business practices in the context of the JMAM-FMAM Alliance, using a mix of different theories. The theoretical approach was reinforced with interviews with two highlevel executives of the JMAM-FMAM. The study identified disparities between organizational cultural of Japan and France that affected the Alliance in the long term and suggested an alternative solution to help project managers to improve strategies for intercultural collaborations.
\end{abstract}

Keywords: Japan; France; corporate culture; automobile industry; multicultural projects.

This is an Open Access article distributed under the terms of the Creative Commons Attribution License, which permits unrestricted use, distribution, and reproduction in any medium, provided the original work is properly cited.

Resumo: A globalização exerce um grande impacto sobre os processos de gerenciamento de projetos, adicionando a complexidade para operar além das fronteiras e em ambientes multiculturais. Por esse motivo, as colaborações internacionais exigem que assuntos culturais estejam no centro das estratégias de negócios, evitando assim, conflitos com as práticas do país anfitrião. O Japão, por exemplo, possui práticas de negócios únicas em comparação com a maioria dos países ocidentais, e essas devem ser consideradas em uma eventual mudança de cultura organizacional. O objetivo foi compreender a importância de trabalhar a cultura organizacional em projetos internacionais. Foram descritas peculiaridades da cultura empresarial japonesa e como foram formadas, comparando com as práticas empresariais ocidentais. Um estudo observacional do projeto inicial da aliança entre multinacionais fabricantes de automóveis japonesa (JMAM) e francesa (FMAM) foi aplicado para destacar contrastes das práticas de negócios japonesas e ocidentais. Para compreender as complexidades da cultura de diferentes ângulos, este artigo dividiu a pesquisa em diferentes fases, cada uma explorando os diferentes aspectos culturais das práticas empresariais japonesas e francesas, no contexto da Aliança JMAM-FMAM, fazendo uso de um mix de diferentes teorias. A abordagem teórica foi reforçada, com entrevistas com dois executivos de alto nível do JMAM-FMAM. Várias disparidades culturais entre o Japão e a França que impactaram a Aliança no longo prazo foram apontadas, e uma solução alternativa foi sugerida para ajudar os gerentes de projeto a melhorar as estratégias de colaborações interculturais.

Palavras-chave: Japão; França; cultura corporativa; indústria automobilística; projetos multiculturais. 


\section{Introduction}

According to the Project Management Book of Knowledge (PMBOK) (PMI, 2017), Enterprise Environmental Factors (EEFS), established as an input in most project management processes, can significantly influence the success of a project. The PMBOK classifies EEFS as internal, defined by corporate culture, and external, represented mainly by social and cultural issues. Globalization has dramatically affected EEFS, as projects started to be executed across borders and into multicultural environments.

In projects involving Alliances between institutions of different countries, project managers must place cultural affairs at the center of business strategies. Additionally, if the collaboration requires the comprehension of corporate culture, and it values, national culture aspects should be constituted as part of the solution because cultural discord may lead to the deterioration of a successful partnership over time. Project managers have attempted to create global strategies to manage with such cultural issues; however, even though globalization has increased the interaction and communication among nations, "once size fits all" solutions fail to acknowledge the peculiarities of local environments (Abyad, 2017).

Japan, for instance, has unique business practices if compared with Western countries, and although Japan is a developed country, regarded as the most technologically advanced country in the world (WPR, 2020), is, in essence, a village society, which values the unit of the group and has a strong tendency to exclude outsiders (Bowie, 1993). This exclusion tendency has been persistent over Japanese history and must be considered by western companies when establishing alliances with Japanese counterparts. Interventions in Japanese companies must be strategically conceived within Japanese culture, to synchronize with the local business traditions and not merely to adequate to international business practices (Bowie, 1993).

The PMBOK (PMI, 2017) highlights the importance of tailoring due to every project's uniqueness, considering constraints such as the organization culture and the project environment. This paper recognizes the National Culture of great relevance in the project environment, directly influencing the company's organizational culture.

Hence, this study demonstrates the importance of respecting national culture's boundaries in organizational culture change of international projects. Thus, it will describe some peculiarities of Japanese business culture and how they were formed while making a parallel comparison with western business practices. Ultimately, this paper intends to deliver useful knowledge to help project managers improve inter-cultural collaboration strategies.

\section{Materials and Methods}

To highlight the contrasts of Western business practices with the Japanese modus operandi, this paper has applied, as an observational study, of the kick-off project of an Alliance between a Japanese multinational automobile manufacturer (JMAM) and a French multinational automobile manufacturer (FMAM).

In order to gather multiple sources of evidence, the observational study research was divided in multiple dimensions developed in five phases: Phase 1: Literature review of the Alliance - and the historical events which led to the formation of the Alliance; Phase 2: Literature review of the works related to cultural differences between the countries involved in the Alliance, in specific the theories of Trompenaars \& Hampden-Turner (1993) and Cameron and Quinn (2011); Phase 3: Literature review about the "Kaikaku" Project Management (KPM) described by Ohara and Asada (2009); Phase 4: Interviews with high ranked managers from each company that were directly involved in the formation of the Alliance; and Phase 5: Research of the different dimensions of the Synergy, a concept so widely used to describe the Alliance.

\section{Understanding the Alliance}

The JMAM was at risk of bankruptcy due to Japan's chaotic financial crisis during the economic stagnation known as the Lost Decade, which followed the Japanese asset price bubble's collapse in the 
early 1990s. Without any help from the local government, the JMAM had no other choice but to look for a partner outside its borders (Ghosn et al., 2005). The JMAM-FMAM Alliance was signed on March 27 of 1999 and was a pioneer of its kind involving a Japanese and a French company due to the very distinct differences in each company's corporate culture. The Alliance's management structure was idealized to define a common strategy and manage synergies between companies (NMC, 2003).

Japan had a long-lasting culture of hostility against foreign companies entering the Japanese market, but because of the magnitude of the crisis at that moment, the country had no other choice but to be welcoming to the Alliance. The Alliance was unique in many aspects, but it was praised for the perfect complementation of two companies with no apparent direct competition. On one side, according to Ghosn et al. (2005), the FMAM would bring its innovative design, marketing, platform strategy, and financing of sales and services, while the Japanese counterpart would lead to quality and manufacturing productivity. Ghosn et al. (2005) explain that the NRP, meant to restore the JMAM profitability, consisted of three parts:

1. The closure of an inefficient factory

2. Change the "Keiretsu" system to a bidding/awarding process.

3. Product development innovation

The change in the "Keiretsu" system was a substantial change for the JMAM. The "Keiretsu" system started to be propagated during the Meiji Restoration (1868-1912), with small family-owned enterprises specialized in separate businesses across Japan. The system evolved into a grouping of enterprises with close business relationships and cross-shareholdings. The "Keiretsu" system is based on the partners' high personal involvement, allowing both strong and weak businesses to grow together and be protected from hostile bidding systems, especially from foreign companies (Twomey, 2020).

"Keiretsu" became the norm in several industries in Japan, notably the car manufacturing industry. Experts argue that one of the superior features of the "Keiretsu" system is that it enables Japanese companies mainly car manufactures - to focus on research and development, improving product quality and providing job security to employees in the Keiretsu family, as opposed to the opportunistic features of the bidding model. However, one specific issue of the system is that it blocks other companies' entry into the Japanese market, depriving companies to enjoy the economic benefits of market competition (Bowie, 1993).

Considering the importance of the "Keiretsu" system to Japanese business culture, part two of the NRP was analyzed according to the impacts caused to the JMAM and their suppliers' network.

\section{Cultural Dimensions}

According to Trompenaars and Hampden-Turner (1993), the management of cultural differences between partners of business requires special attention, reporting that $70 \%$ of integrations fail due to cultural differences. His model of national cultural differences is a framework for cross-cultural collaboration, divided into seven cultural dimensions: 1. Universalism x Particularism; 2. Individualism $\mathrm{x}$ Communitarianism; 3. Specific x Diffuse; 4. Neutral x Emotional; 5. Achievement x Ascription; 6. Sequential Time $x$ Synchronous Time; and, 7. Internal Direction $x$ Outer Direction. The cultural dimension scores of Japan and France are the following in Table 1:

According to Trompenaars and Hampden-Turner (1993), the discrepancies between Japan and France are the following: 1 . Specific profile of France versus Diffuse profile of Japan. Specific cultures tend to have low personal involvement in business, while diffuse cultures usually adopt a high personal involvement in the business; 2 . Neutral profile of Japan versus Personal profile of France. Neutral cultures will tend to conceal emotions, while Emotional cultures will tend to emotional expressions or outbursts; 3. Internal Direction of France versus Outer Direction of Japan. Internal Direction cultures believe it is up to them to shape the market, while Outer Direction cultures tend to go along with the business environment. 
Table 1. Cultural Dimension Scores for Japan and France

\begin{tabular}{|c|c|c|}
\hline Dimensions & Japan & France \\
\hline Universalism & 56 & 43 \\
\hline Individualism & 28 & 36 \\
\hline Specific & 32 & 67 \\
\hline Neutral & 80 & 39 \\
\hline Achievement & 39 & 54 \\
\hline Past & 23 & 39 \\
\hline Present & 38 & 30 \\
\hline Future & 38 & 31 \\
\hline Internal & 10 & 65 \\
\hline
\end{tabular}

Source: THT Consulting (2020)1 and Trompenaars and Hampden-Turner (1993)

The data provided by THT Consulting (2020) was interpreted with a radar graphic for a visual representation of the differences highlighted, the dimensions related to time were summed up to provide a better visual of the main discrepancies between both countries. Thenceforth, each of the highlighted dimensions was interpreted according to the business philosophy of each country.

\section{Organizational Culture}

Organizational culture is a social attribute that unifies an organization together, reinforcing continuity and consistency through adherence to a clear set of consensual values. To be successful, the organizational culture must match the demands of the competitive environment. That is to say, the shaping of the Organizational Culture must be aligned with the environment in which the company exists (Cameron and Quinn, 2011).

According to the theory of Cameron and Quinn (2011), Corporate Culture, as shown in Figure 1, can be classified as Clan, Adhocracy, Market, and Hierarchy: 1. Clan oriented organization cultures are like extended families, focused on the "we", with a strong sense of belonging in a group, rewards are collective instead of individual, and employees share the same values, beliefs, and goals; 2 . Adhocracy oriented organization cultures are focused on innovation and aim to "do things first" to develop new products and services for the future; 3. Market-oriented organization cultures function as a market itself focused on transactions with external constituencies; and 4. Hierarchy oriented organization cultures are structured and controlled, focusing on stability, efficiency, and highly consistent products.

Additionally, concerning values that shape corporate culture in Japan, Takeuchi (2013) compares what he calls "Wise Capitalism" against the "Wall Street capitalism". According to Barría (2020), the "Wise Capitalism" practiced in Japan is composed of three pillars: 1. Longevity: Long-run strategic business plan. Some companies only develop strategic plans for the next five years, while many Japanese companies tend to think about the next 100 or 200 years; 2. Leadership: Inside outgrowing perspective. External metrics do not guide achievements, which means that the firm is willing to follow the leader's intuition in emergencies or catastrophes. In Japan, a company's strategy is based on the founder or executive director's dream; and 3. Empathy: In times of crisis, the Japanese avoid layoffs and cost reduction. A company is an instrument of society; the latter will allow its existence as long as it offers values to society.

Cameron and Quinn's (2011) framework and Takeuchi (2013) “Wise Capitalism" theory were used for the analysis of the JMAM's corporate culture, based on the company's annual report (NMC, 2002) after the conclusion kick-off project.

${ }^{1}$ Trompenaars Hampden-Turner Consulting (THT Consulting). 2020. Country Profile (personal message). Message received by Izabela lopes, e-mail: <izabela. lopes@usp.br>, at 14th of April 2020. 


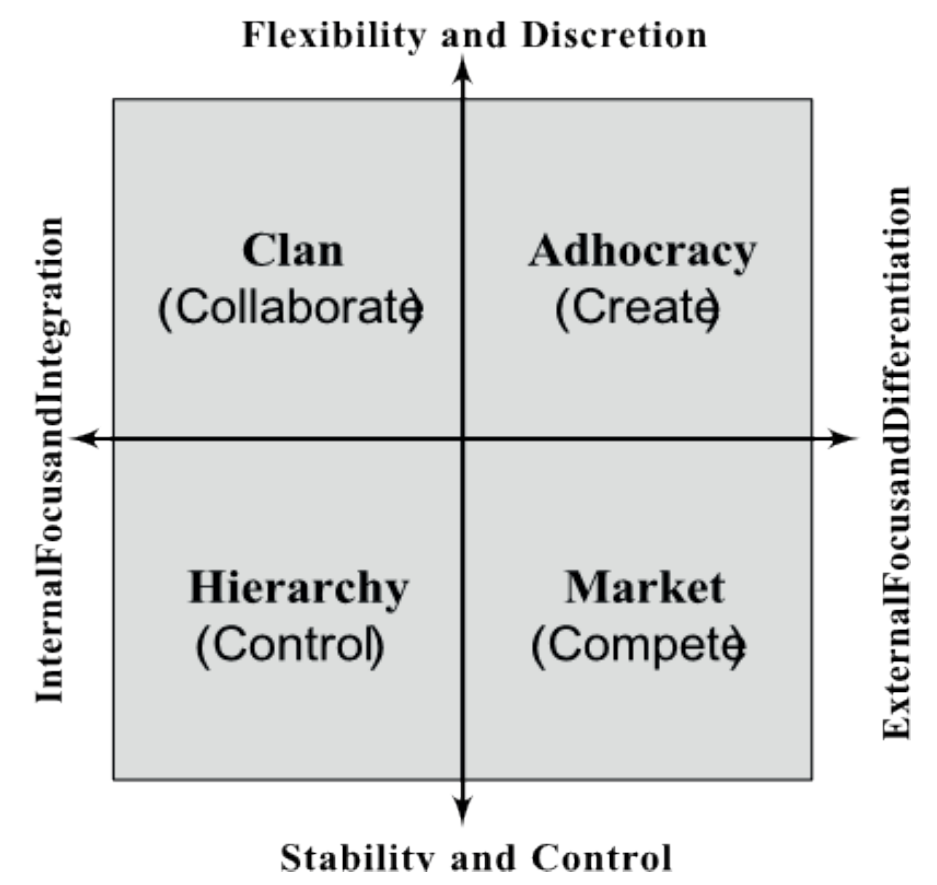

Figure 1. The Competing Values Framework Source: Cameron and Quinn (2011)

\section{Japanese Project Management}

"Kaikaku" Project Management (KPM), also referred to as Japanese Project Management, is an improved paradigm of P2M, which is the Japanese version of project and program management, which encompasses the Japanese concepts of "Kakushin" (innovation), "Kaihatsu" (development) and "Kaizen" (improvement). P2M/KPM has a mission-driven approach, leading project development through value creation in a complex and changing environment (Bredilet, 2009). PM2 is defined as second-generation project management, tackling business and technical issues. Whereas the Project Management Institute (PMI), standard, focuses more on the control aspect of governance and the traditional project-based tools and techniques, including planning, execution, control, and monitoring. Hence, P2M focuses more on patterns and relationships (Thiry, 2009).

According to Bredilet (2009), the "Kaikaku" reforms were responsible for the survival of several Japanese companies during the "Lost Decade", the economic crisis that hit Japan in the late 1990s, the same economic recession that led to the Alliance of the JMAM with the FMAM. During the "Lost Decade", other Japanese companies looked for innovative reforms of business management to survive the recession and regain their global competitiveness, giving birth to the "Kaikaku" Project Management (KPM). "Kaikaku", which means radical change, more than a project management methodology, offers a framework procedure for organizational culture change needed in times of economic crisis (Bredilet, 2009).

"Kaikaku" reforms, according to Imaguchi (2009), are broken down into three steps: a. Analysis of the current organization characteristics such as values and norms; 2 . Clarification of the difference between the ideal standard norm and the present standard norm; and 3. Design of a suitable norm for the organization.

To accomplish "Kaikaku" effectively, four conditions need to be established: 1 . The ability to take in and communicate information reliability and validity; 2 . Internal flexibility and creativity to make the change; 3 . Integration and commitment to the goal of the organization; and 4. Internal climate support and freedom from threat.

The process for achieving such conditions consists of three stages: 1 . Freeze: this stage creates the wiliness to change, and the opportunity to develop new attitudes and behaviors based on the acquired knowledge; 2. Change: the reform process stage; and 3. Freeze again: the establishment of a new organization structure. 
KPM was the first project management guide to address enterprise-level project management issues directly. Although KPM is a process of organizational culture change, it did not change the basic Japanese methods of the organizational decision-making process and the human relations among stakeholders. Mostly, it kept the Japanese essence of managing for its employees as opposed to the Shareholder Wealth Maximization (SWM) techniques, so familiar to the western management model. KPM was created by and for the Japanese industry, built on strong Japanese values, where human resources are still considered the most critical asset of a firm. Thus, "Kaikaku" offers a framework for sustainable change, accomplished by the close examination of the given environment, to learn new behavioral patterns and attitudes to establish new information and concepts (Imaguchi, 2009).

Toyota's strategy for the reformulation of its "Keiretsu" under the KPM framework is presented as an alternative to the competitive model implemented by the JMAM.

\section{Results and discussion}

\section{The JMAM-FMAM Alliance}

Considered the most successful Alliance in the automobile industry, the JMAM-FMAM Alliance became the number-one automotive group worldwide (Porter, 2018). In 2017, the FMAM, headquartered in Boulogne-Billancourt - France, with 179.565 employees in 39 countries, sold 3.76 million vehicles (NMC, 2003); in the same year, the JMAM, headquartered in Nishi-ku, Yokohama - Japan, with 136,134 employees in 27 countries, sold 5.81 million vehicles (NMC, 2018).

Although financially successful, the JMAM-FMAM Alliance has challenged the Japanese culture in many ways. For instance, from the three phases of the NRP, the dismantling of the JMAM's "Keiretsu" can be argued to be the most audacious because it meant a break with the Japanese traditional business culture.

However, because the main problem of the JMAM was economical, the goal was clear, cut cost, and in that context, the JMAM's "Keiretsu" system, considered problematic by the FMAM's executives, had to be dismantled. Before the Alliance, the JMAM had shares in 1,394 auto-component suppliers and other firms in its "Keiretsu", but during the NRP, the Alliance leader only considered four of those to be indispensable (Shirouzu, 1999).

The replacement of the "Keiretsu" proved to be unsustainable over time and started to fail, as most vendors got tired of the competition, knowing that reducing prices and improving quality would not guarantee reciprocation. Consequently, not only the JMAM had a drop in parts quality, but also it was unable to increase car production when the Japanese economy revived, for not being able to procure more steel from its major supplier who refused to increase the volume beyond its commitment (Kinoshita, 2009).

To restructure the company's purchasing structure, the JMAM announced in 2004 a new policy that represented a reevaluation of the "Keiretsu". The new policy consisted of increasing the investment in one larger supplier and establishing a collaboration program between the company's engineers and the suppliers in process-improvement projects (Aoki and Lennerfors, 2013).

However, in the light of the recent scandals involving the leader of the Alliance, Carlos Ghosn, the JMAM's "Keiretsu" currently find themselves back where they started, suffering from the company's demands, which is currently requesting price cuts that are double the size of what other companies are lobbying for. When the JMAM's sales were steadily increasing, the company's "Keiretsu" managed to cope with the price cuts imposed by NRP, but with the recent sales declining, suppliers have no choice but to increase transactions with other automakers other than the JMAM (Fujimoto, 2019).

Even if the Alliance was considered, in many other aspects, to be groundbreaking, according to Kinoshita (2009), many experts predicted the failure of the Alliance during the years due to the significant organizational and national identity differences between both companies. Susini (2004) highlights that besides the noticeable differences such as language, decision-making process, communication pattern, accountability, and labor-management relations, the most pronounced difference was the individualistic nature of a French company versus the group orientation of a Japanese company. 


\section{Cultural assessment of France and Japan.}

The literature review of the Alliance identified some intrinsic differences in the business management practices of the countries involved in the Alliance, namely, France and Japan; such differences are often attributed to the National Culture factors. THT Consulting BV (2020) has provided data of the National Profile of France and Japan. This data was interpreted in the following radar graph (Figure 2) for a better observation of the main differences between both countries.

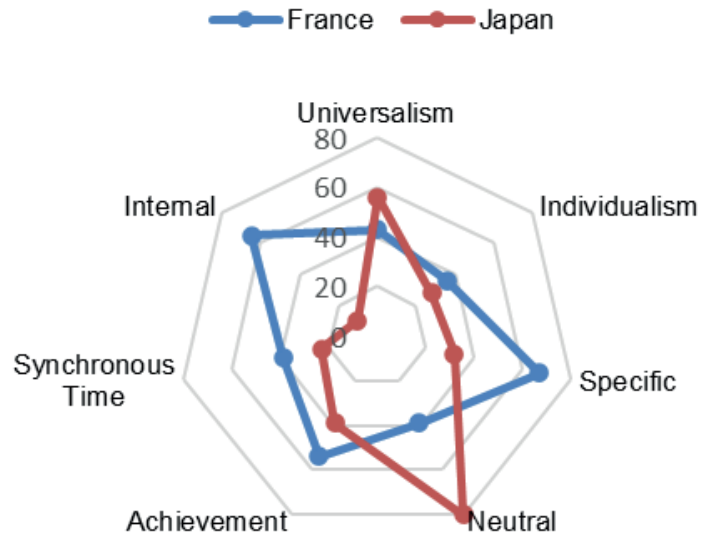

Figure 2. France x Japan - Trompenaars Cultural Dimensions Country Comparison (1993) Source: THT Consulting BV (2020)

The three main differences identified by Trompenaars and Hampden-Turner (1993) are as follows:

1. Specific profile of France versus the Diffuse profile of Japan: The French culture has an intrinsic sense of privacy with a clear distinction between business and personal life (BC, 2019). Japan, on the other hand, believes that good relationships are vital to meeting business objectives. The "Keiretsu" system, previously mentioned, is a good example of Japan's Specific profile.

2. Neutral profile of Japan against Emotion profile of France: According to Trompenaars and HampdenTurner (1993), Japanese delegates will hardly show any personal feelings towards a specific object. France, on the other hand, will often display their opinion publicly. One reason behind this lack of emotional expression by Japanese people is due that courtesy in Japan is an essential social rule that is derived from the concepts of "Honne" (real intention) and "Tatemae" (pretense), referring to people's true feelings, against their public behavior. In Japan, it is essential to avoid confrontation, and for that reason, the Japanese are most likely to hide their personal feelings (Naito and Gielen, 1992).

3. Internal Direction profile of France versus outer Direction profile of Japan: According to Trompenaars and Hampden-Turner (1993), France tends to strike aggressively at the market to adapt to its needs. On the other hand, Japan tends to create long-term plans and hardly deviate from it, and instead of aggressively striking the market, it will wait for the right opportunity and adapt to the outside forces. As Takeuchi (2013) suggests, Japanese companies tend to make plans for 100 years.

The above differences are the output of the philosophy that rules the social norms of each country. According to Tucker (2018), Confucianism is the intellectual force that defines Japan's East Asian identity about philosophical thought and practice. Confucianism, although it has a religio-philosophical dimension, is mainly a social and political regulation focusing on ethical, epistemological, metaphysical, political, and aesthetic issues. Confucianism teachings are related to the individual's pursuit of moral and intellectual perfection, the family's pursuit of harmony and order, and the polity's pursuit of peace and prosperity, and family is the basis of society. Those teachings are heavily integrated into Japanese society and became part of the Japanese mentality and a synonym of its cultural expressions, shaping business practices, and working ethics (Tucker, 2018).

On the other hand, France has had incredibly diverse philosophy schools over its history and has greatly influenced Western philosophy and is considered the cradle of Postmodernism. This individualist philosophy encourages the exercise of an individual's goals and desires, highlighting the individual's importance over the state or any social group (Motak, 2009). 
The fundamental difference in these respective systems' essential elements is that Japan has a grouporiented ideology, while France follows the individualistic nature of Western principles. Using market efficiency as a basis for comparison, such differences can be summarized, as Odawara (1993) points out, the tendency of Japanese companies to prioritize people while Western companies prioritize returns.

Trompenaars and Hampden-Turner's (1993) model helps to translate those ideologies into standard business practices of each group, stressing the main points of divergence that may arise between France and Japan due to their very distinct social, political regulations highlighted above.

\section{Corporate culture assessment}

As aforementioned, each country's social and ethical philosophy will help shape people's behavior and just as any other group. Business organizations will be a place where individuals will share their values, shaping their mutual interactions, which is governed by corporate culture. While Trompenaars and HampdenTurner's (1993) dimensions were constructed on national cultural aspects, influencing work-related values, Cameron and Quinn (2011) grouped those working values into the organizational culture.

To analyze the JMAM's Organizational Culture, it is essential to understand the company's fundamental nature in its environment. In Japan, as indicated by Kobayashi (1993), the corporation is a member of the community, obliged to contribute to the nation's greater good. Business Organizations are a constituent member of society and must fulfill its role as an economic subsystem, and its activities must be generally accepted by the society to which it exists. Businesses can be engaged in economic activities only within the range of social acceptance, and if corporations want to challenge any existing social restrictions, it must, however, work within the framework or rule of society.

Kobayashi (1993) also points out that logic and rationality have been the primary goal of the Japanese automobile industry, with the introduction of robots and "Kanban-hooshiki" (the just-in-time method of parts supply) in the short term, and "Keiretsu" system in the long term. He also highlights that, since the end of the bubble economy, Japanese business became more capitalistic, but Japanese corporations are still expected to maintain the Japanese values in the corporate strategy, such as the Confucianism virtue of caring for others. In other words, Japanese corporations are expected to serve society.

According to the 2002 JMAM's annual report, right after the conclusion of the NRP, the JMAM's vision can be analyzed according to the following quadrants in Figure 3.

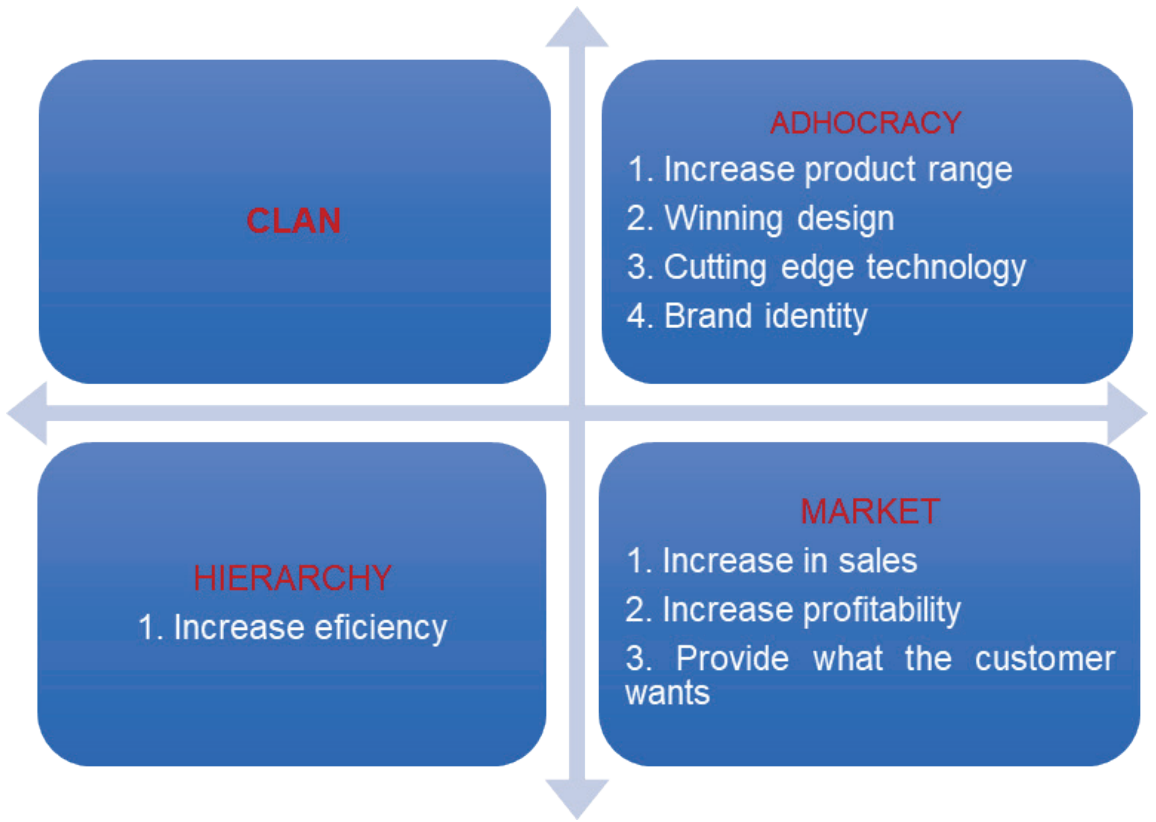

Figure 3. The JMAM's Organizational Culture Analysis

Source: Nissan Motor Corporation (2002) 
The JMAM's annual report expresses a clear vision towards the market and the shareholders' profits, two concepts that go against Takeuchi's (2020) "Wise Capitalism".

According to Cameron and Quinn (2011), although organizations are likely to have a dominant corporate culture, automakers are expected to cover all four culture types in their vision statement due to the global automobile market's complexity. However, as previously observed in Figure 3, the company's vision the NRP did not cover any measures under the spectrum of the Clan Culture.

Additionally, if the JMAM's Corporate Mission is analyzed by Takeuchi's (2020) Japanese “Wise Management" pillars, we may conclude the following: 1. Longevity. Unlike traditional companies, the JMAM did not possess a strategic business plan in the long run; 2. Leadership. Unlike its major local competitor, Toyota, the JMAM's founder, did not pass on a business philosophy or guiding principles to shape the company's values (Nayebpour and Saito, 2007); 3. Empathy. Since the beginning of the Alliance, the JMAM has prioritized cost reductions at all costs- one of the Alliance's first measures was to close a factory in Saitama during a period of economic recession in Japan (Ohara and Asada, 2009).

Therefore, even if the source of the company's problem was financial, it can be argued that the prioritization of financial achievements left some critical aspects of the local culture out of the company's organizational culture. In other words, the JMAM's organizational culture does not seem to be in harmony with Japanese society's cultural norms. Other Japanese companies faced similar financial difficulties during the "Lost Decade" and opted for organizational culture change as a restructuring strategy. However, those companies had a different approach, placing Japanese values at the center of decisions, giving birth a resilient concept of Project Management, the "Kaikaku" Project Management (Bredilet, 2009).

\section{Japanese Project Management}

The Kaikaku process, previously described, can be illustrated as in Figure 4.

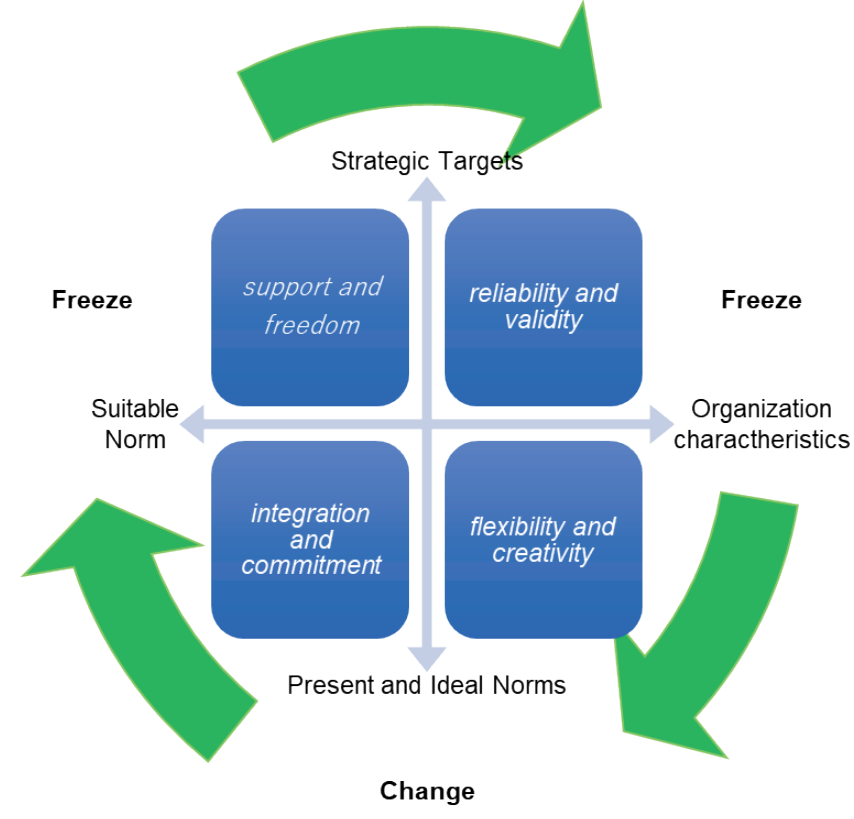

Figure 4. Kaikaku Reform Process

Source: Adapted from Ohara and Asada (2009).

As it may be observed in Figure 4, the "Kaikaku" reforms offer a dynamic framework for organizational culture change. The framework is structured to analyze the organization's most critical aspects before the design of a suitable norm to achieve strategic targets. Additionally, the model is highly cooperative, structuring the achievement of the desired change around the group's collaboration, one of the essential values of Japanese society. 
The "Kaikaku" reform was successful in several Japanese organizations, including the JMAM's direct competitor in the territory, Toyota, which achieved its goals through "Kaizen", meaning improvement, a Japanese concept, which refers to on-going or continuous improvement. Toyota is considered, by Kinoshita (2009), as the company that best applied the "Kaikaku" reform. Toyota, when faced with the lack of competition issues of the "Keiretsu" system, instead of opting for a break with the suppliers, the company not only expanded the local production but also invested in product enhancement and revived and reinvented its "Keiretsu". As mentioned by TMC (2012), instead of the traditional, obligationalbased relationship that lasted for decades supplying individual parts above the competitive price, Toyota innovated the "Keiretsu" system in four ways: 1. Internationalization of the Keiretsu system; 2. Detailed forecast of price among global companies before setting target prices for long-term suppliers; 3. Procurement of an integrated system of components instead of individual parts; 4 . Involvement of suppliers at the planning stage to enhance their ability to provide these integrated systems.

Additionally, in 2000, with the competitive pressures for rapid global growth, Toyota re-reinvented the purchasing system. Called "Construction of Cost Competitiveness for the 21st Century" (CCC21), the plan aimed to reduce costs by $30 \%$ over three years. The plan consisted of selecting suppliers based on globally competitive target prices and the provision of sophisticated component systems rather than just individual parts. However, it is essential to highlight that even with the strict demands and the expansion of the sourcing pool, Toyota's suppliers' association ("Kyohokai") continued to have an emphasis on goodwill and trust, remaining relatively stable over the years, e.g., from 1991 to 2011 fewer than 20 of about 200 companies withdrew from the "Kyohokai" (TMC, 2012).

Toyota has kept the diffuse dimension of Japanese management, with high personal involvement in business, as Trompenaars and Hampden-Turner's theory previously highlighted. That is to say, instead of turning the back on usual suppliers when others offered new prices, Toyota has helped many suppliers meet its changing needs by organizing "study groups" and dispatching engineers to help vendors improve efficiency and quality and bring prices down. Thus, rather than suppressing the keiretsu system, Toyota reformed the system itself, creating a new type of "Keiretsu", deepening trust, collaboration, and educational support in a more open and global and cost-conscious new form of "Keiretsu", becoming one of the company's most significant advantages (Aoki and Lennerfors, 2013).

\section{Interviews}

To support the theoretical approach, two high-ranked managers from each company were interviewed about their personal experiences in the Alliance. The interview was conducted in Japan in October 2020. At the time of the formation of the Alliance, the JMAM's Representative was involved in the manufacturing processes of the company, while FMAM's Representative was directly involved in the formation of the Alliance.

A list of questions (Appendix 2) was prepared with general questions about the Alliance and the JMAM's corporate culture change and its implications in the Japanese business culture. The interviews were in person and online through the Zoom platform, where only the interviewee and the main researcher were present. Each interview was recorded in audio and/or video and was kept in the strictest confidence. The respondents were interviewed individually by Zoom and in person. The interview was divided into different categories according to the phases of the research and the answers were then interpreted for the reinforcement of the theories presented.

The first round of questions was about the JMAM-FMAM Alliance, where each company's representative was asked questions regarding the cultural impacts experienced in the Alliance's processes. The repercussions of the break of the JMAM's "Keiretsu" were summarized in Table 2:

As observed in Table 2, the break of the "Keiretsu", proved to be problematic for the JMAM in the long-term, affecting the competitiveness of the company in Japan while also affecting the identity of the JMAM as a Japanese company. Moreover, according to the JMAM's representative, it affected the company's innovation capacity, which was the main role of the JMAM in the Alliance. Nevertheless, the JMAM has recognized the issue and aimed to change the relationship with the vendors, abandoning the competitive model and returning to the Japanese way of collaboration. 
Table 2. Summary of the interview with high-rank managers of the JMAM-FMAM Alliance regarding the "Keiretsu" system FMAM's Representative JMAM's Representative

1 What were the main issues associated with the dismantle of the JMAM's Keiretsu?

The competitive model created trusting issues with Suppliers did not allow the JMAM to see their advances, and the supplier and affected the JMAM's innovation the company struggled to compete, as they were not given capacity. the best teams.

2 In your opinion, why is the JMAM is once again pressuring the company's vendors? (Demanding prices that are around $30 \%$ less then what Toyota for example is lobbying for) What could be the impact of this business decision?

The JMAM-FMAM purchasing organization was the The "Keiretsu" is under distress again because, under the first synergy pole between both companies, and it recent crisis, the only thing that the JMAM can do is to became the most critical buying platform in the world. control the TDC (total delivery cost). The new management The company was directed by the FMAM, who were recognized the issue and plans to return to the old long-term always efficient in lowering costs, to the point where it collaboration model. deteriorated their relationship with the suppliers. With the company's current issues, it is not surprising they are pressuring again for cost reduction.

3 In your opinion, should the JMAM insist with the current competitive model or it should follow the local automakers tendency for the "keiretsu" system?

The perfect supply system model would be A hybrid system, taking advantage of the beauty and somewhere in between the "keiretsu" and the the power of the "keiretsu", which is the shared vision of competitive model. It is essential to select a few companies running towards the future with the same goals. suppliers to co-innovate and develop long-term projects. The cost reduction approach on its own is an invitation to failure.

4 What is your general feeling regarding the dismantling of the "keiretsu" system?

The dismantling of the "keiretsu" was rather violent The break of the "Keiretsu" was a social exercise. The JMAM because it broke the type of collaboration typical learned that suppliers are essential partners, and nothing can for Japanese companies, particularly automobile be done without their collaboration. Somewhere along the manufacturers. way, the JMAM stopped being Japanese.

Source: Prepared by the author

The competitive model strategy not only affected the company's procurement system; Carlos Ghosn also completely changed the internal management of the company, flattening the decision-making process and replacing the seniority system for the performance reward compensation system (Nayebpour and Saito, 2007). Both Measures brought to surface the contrast between the FMAM's business practices with the Japanese social ethics. According to Yui (1993), one of the bases of Japanese management is the life-time employment and seniority system. These practices are associated with the social dimension of Confucian Philosophy, which rules the social ethics of Japanese society, in which employees are considered extended family (Taka, 1993). Table 3 summarizes the experiences of the high-rank executives of the Alliance concerning the internal management changes in the JMAM.

Table 3. Summary of the interview with high-rank managers of the JMAM-FMAM Alliance regarding the internal management changes

\section{FMAM's Representative}

\section{JMAM's Representative}

5. What were the consequences of the flattering of the decision-making process and the replacement of the seniority system for the performance reward compensation system?

The advantage of the Japanese seniority system is that the head of the group is extremely fatherly, so he assumes the mistakes of youth or beginners in the group, which is not the case at all in France, where you are alone, nobody will protect you. So, the change was quite violent because they imposed a system of individual performance in a country that only works in groups.

Source: Prepared by the author

In Table 3, both representatives agreed on the issues created by the seniority system's replacement, one of the pillars of Japanese companies. Hence, the infliction of Western values in the JMAM without 
proper adaptation to the Japanese unique business practices illustrates how often it is assumed that the western competitive model is invariant and may be applied across different countries.

To adapt any given practice to a given country, it is vital to establish the main divergences between the country applying the practice and the host country. To support the theoretical evidence of the highlighted differences between the countries involved in the Alliance, the second round of questions was about the 3 (three) before-mentioned main divergences between France and Japan.

Table 4 summarizes the experience of each company's representative, regarding the Specific profile of France versus the Diffuse profile of France, during the JMAM-FMAM Alliance:

According to the JMAM's representative in Table 4, it was not natural for the French delegates to mix business and personal affairs, and although they tried initially, the cultural disparities eventually came to light. The FMAM's representative, on the other hand, although it recognized the apparent difference between business $x$ private, classifies the Japanese relationships as fakes, and with the only purpose to serve their business.

Table 4. Summary of the interview with high-rank managers of the JMAM-FMAM Alliance the Specific profile of France versus the Diffuse profile of France

FMAM's Representative JMAM's Representative

6. According to your experience, did the FMAM acted as if personal relationships do not have much impact on working objectives? Can you name an example?

I agree that there is a more significant frontier During the "honeymoon", the French delegates made between the private and the business in France, but an effort with personal relationships; only after that Japanese personal relationships are false. period, the cultural differences started to emerge; this mixture of business and personal life is unnatural for foreigners.

7. According to your experience, did the JMAM executives tend to pursue good relationships to help meeting business objectives? Can you name an example?

The Japanese look like they are more into the In "Nomikais" you can see the brutality in which individual personal relationship, but at the same Japanese people treat each other. It is a kind of time, the individual does not exist; the person is the harshness that only siblings have, but for them, it representative of a company, so they can even go and works. drink together, but the relationship is not personal.

Source: Prepared by the author

Furthermore, Japan and France have clear distinctions regarding emotions, as expressed by each company, represented in Table 5.

Table 5. Summary of the interview with high-rank managers of the JMAM-FMAM Alliance regarding the Neutral profile of Japan against Emotion profile of France

8. Regarding the publicly display emotions. Is it correct to affirm that Japanese delegates will hardly show any personal feeling towards the specific object while the French delegates will often publicly display their option?

Japanese meetings, for example, it is just a register The Japanese hardly show any emotion unless they are of decisions. A top-down structure in Japan is like the outraged.

army; everyone obeys without questioning. So, there is Some French delegates were quite violent, but because no space to express any kind of emotion. they were from the "elite" of the Alliance, the Japanese

In France, a decision is a base of discussion so we can accepted; that behavior was not accepted from other transmit more feelings in a meeting. delegates.

Source: Prepared by the author

In Table 5, the FMAM's representative suggests that Japanese employees will obey orders without question, while JMAM's representative highlights how violent some French delegates were and the fact that this behavior was accepted from some members of the Alliance but not tolerated from other delegates.

Lastly, Table 6 summarizes the experience of the JMAM-FMAM representatives regarding their relationship with the market environment. 
In Table 6, while both representatives agreed on the French tendency to strike the market and the Japanese tendency to follow long-term plans, the FMAM's representative highlights that the Japanese long-term vision is a continuity approach rather than a plan, there is to say, rather than a strategy, longterm vision express the difficulty of Japanese to cope with drastic change.

Having established the differences between France and Japan cultural dimensions during the Alliance in Tables 4-6, the JMAM-FMAM' representatives were then asked in the third round of questions about how the particularities of Japanese organizational culture and whether they were taken into consideration for the change of the JMAM's corporate culture. Table 7 summarizes the cultural impacts identified during the reshaping of the JMAM's Organizational Culture during the NRP.

Table 6. Summary of the interview with high-rank managers of the JMAM-FMAM Alliance regarding the Internal Direction profile of France versus Outer Direction profile of Japan

\section{FMAM's Representative JMAM's Representative}

9. From your experience, is it true to affirm that Japanese companies tend to create long-term plans and hardly deviate from it? Can you name an example in the automobile industry?

In France, we start from zero each time. We always try The Alliance leader manipulated a lot of the natural to create new concepts to attack the market from a mechanics of the automobile industry to keep the high different angle. profits of the JMAM.

10. From your experience, is it true to affirm that France tends to aggressively strike the market? If so, do you think such tendency manifested itself during the Kick-off Project?

In Japan, they are more into continuity; they can make the Toyota is an excellent example of the Japanese longsame car for 40 years. So, it cannot be considered strategy, term vision. They do not overreact to short-term failure. but rather planification, that is to say, to keep doing the When they first invested in hybrid cars, it was a disaster, same thing for as long as possible. When they make but they persisted according to the plan, and today progress, it is always small steps, but never in the rupture. Toyota is known as a technology company.

Source: Prepared by the author

Table 7. Summary of the interview with high-rank managers of the JMAM-FMAM Alliance regarding the JMAM's organizational culture change

\section{FMAM's Representative}

11. If you could identify one dominant organizational culture for the Japanese automobile industry, what would it be?

Japan is a country that works in a group, so there is a tendency for Japanese companies to have a clan culture.

Before the Alliance, the JMAM had a clan culture and a hierarchy culture on some levels, especially regarding the consistency of products. After the Alliance, the company's culture shifted towards the market and the tendency for individual performance

12. If you could choose one dominant organizational culture to identify the JMAM before and after the Kick-off project, what would they be?

There were no cultural considerations whatsoever Before the Alliance, the company's dominant corporate or any willingness to understand for that matter. Carlos Ghosn was focused on the action; he saw the Japanese as machines that were there to perform.

culture was Clan, especially in the anonymousness of the operations; it was always the group and never the individual. The change was overnight, Carlos Ghosn cut 20 thousand jobs (which never happen in a Japanese company), and the focus of the company became the customer and the shareholders.

13. How was the Corporate Culture change conducted in the JMAM? Were there considerations for the Local cultural in general?

There was no cultural consideration for the change. All Japanese decision-making processes were discarded; in the end, all the westerners were the ones making decisions. For example, the JMAM decided not to apply for Japan Taxi because it was not profitable but making a taxi in Japan is not to make money, which is to serve the society, which is the primary goal of any Japanese company.

Source: Prepared by the author

In Table 7, both representatives highlighted the importance of the notion of "clan" in Japan and recognized it as the dominant culture in the JMAM before the Alliance. Additionally, both representatives 
agree on the shift from a clan culture to a market culture and the lack of consideration for the local culture in the organizational culture change.

In the last round of questions, each representative was asked their opinion about Toyota's tactics to deal with the "Keiretsu" system issues. The suppression of the JMAM's "Keiretsu" was previously mentioned as the Kick-off project's most audacious decision. Table 8 summarizes the opinion of each company's representatives regarding the "Keiretsu" reforms conducted by Toyota and whether this strategy would have worked in Japan.

Table 8. Summary of the interview with high-rank managers of the Alliance, regarding Toyota's approach to "Keiretsu". FMAM's Representative JMAM's Representative

14. Was Toyota's strategy to internationalize its "Keiretsu" better than the decision taken by the JMAM?

Toyota has always been smarter than JMAM, and they Toyota strategy was smart, a hybrid "keiretsu", where always had been more assertive in the notion of the you take advantage of the power of "keiretsu", which is "keiretsu" and general quality. However, Toyota is not this shared vision of two companies running towards the same in Japan as they are abroad; in France, for the future with the same goals. example, the procurement model is much closer to the French model.

Source: Prepared by the author

Toyota's corporate culture change was successful because even though the company has a global vision, it acted locally, maintaining Japanese values at the center of strategic decisions. In Table 8 , the FMAM's representative stresses that Toyota tends to adapt to the environment in which they operate, and when in France, for example, instead of forcing the "Japanese way", it adapts to the local customs. The JMAM, on the other hand, adopted practices unfamiliar to its local market that allowed the company to grow internationally but ended up weakening its position in his own home country, affecting its global business in the end.

\section{Conceptualization of National culture-shaping Corporate Culture}

Carlos Ghosn, on several occasions, emphasized the cultural aspects of the JMAM-FMAM Alliance, highlighting the Alliance's unusual business strategy and emphasis on diversity. In the annual report of 2002, following the Kick-off project's conclusion, the JMAM claimed that the groundwork was laid and the Alliance with the FMAM provided synergies and strengths to meet upcoming challenges (JMC, 2002). Nevertheless, through literature research and each company representative's experience report, this paper has identified many cultural discrepancies between both countries and how that affected The JMAM. Thus, there are questions about the structure of the Alliance if the synergy concept was indeed applied.

Figure 5 illustrates the synergy concept of two highly distinct cultures in the world market. In this sense, The JMAM's organizational culture change, if designed with strong cultural awareness, would have evolved to trespass the borders of each country's national culture, and both companies would have created a new system of a perfect organizational culture syncretism.

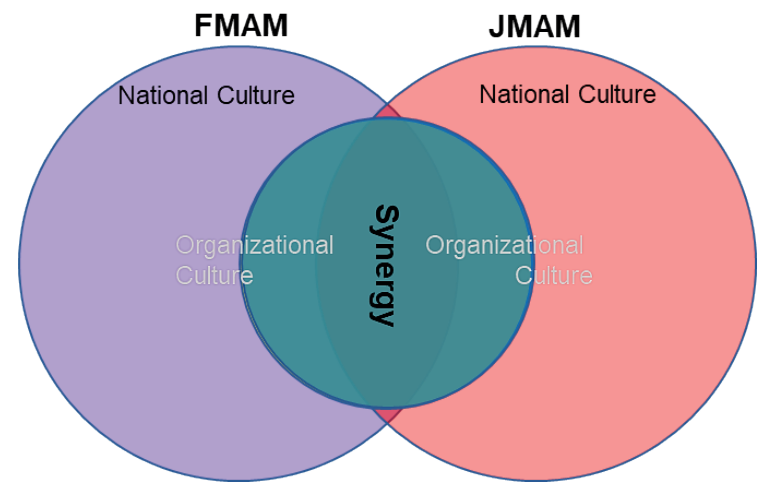

Figure 5. Cultural Synergy, the interaction of culture for a greater effect Source: Prepared by the author 
Unfortunately, because of the power imbalance of the world market, the idea of corporate culture synergy is an ideal far from reality. In the JMAM-FMAM Alliance case, although successful for almost 20 years, was very hostile against central business practices of Japan's business culture, impacting the alliance success. The biggest paradox in the message sent by the Alliance is that while Carlos Ghosn highlighted the importance of recognition and respect for differences, he also defended the idea that the culture that should be preserved was the corporate identity and no longer the national identity (Ghosn et al., 2005).

This behavior can be explained if we apply Trompenaars and Hampden-Turner's (1993) model in Figure 1 in this intervention analysis. France's Internal Direction represents western nature to control change, and this is precisely what the Alliance's leader did with its drastic measures to reshape The JMAM's organizational culture. It can be argued that such an approach was rather a foreign occupation than the reach for cultural synergy. Additionally, as previously highlighted, Japan's Outer Direction profile would explain why the Japanese management of JMAM's accepted the changes that were imposed by the French partner with little resistance, considering their weak position at the time.

As economic globalization progresses, interdependence within countries will increase, but contrary to civilization, that can easily extent itself out of national boundaries; culture is not provided with the same flexibility and tends to stay within national borders. (Nagayasu, 1993). Thus, it is important to take cultural aspects at the center of the company's strategic decisions.

A successful Alliance between two or more very distinguished cultures then requires the integration of cultural awareness into business strategies and operations. Although it may be challenging to create an innovative corporate culture for collaboration outside national borders, it is vital to keep the essence of each culture involved. Figure 6 illustrates the correlation between Corporate versus National Culture of two foreign companies and suggests a balance zone for cultural partnership stability.

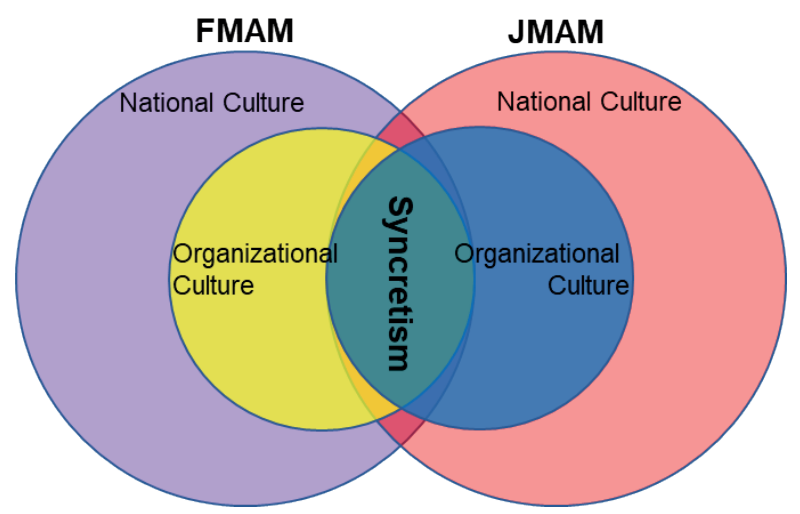

Figure 6. Cultural Syncretism, attempted reconciliation of cultural differences

Source: Prepared by the author

As Trompenaars and Hampden-Turner already established it (1993), culture is the personification of a given group identity. While national culture unifies the country, allowing people to recognize each other as part of the same group, the business culture will work in the same way in the national market; it is an interaction currency that will allow companies to collaborate inside the national borders. The NationState, in its turn, has a role in setting the laws to control the market and influence the interactions between players, and shaping the laws that control the market. Thus, changing corporate culture will only go as far as the business culture allows, and business culture on the other hand is heavily shaped according to national culture.

To promote the concept of syncretism in the tailoring of organizational culture change from another cultural perspective, this paper suggests an integration of the presented models in four steps:1. Trompenaars and Hampden-Turner's (1993) model for the identification of the most contrasting cultural dimensions between the countries involved, from the point of view of the county to be intervened; 2 . Local research, for the selection of the cultural characteristics that are most rooted in the business environment in which the company exists; 3. Cameron and Quinn's (2011) framework for identifying the company's current dominant organizational culture and the desired organizational culture; 4. Application of the "Kaikaku" framework for 
the organizational culture change.The differences discovered in step 1 and step 2, should be placed at the center of the strategy in shaping the desired organizational culture.

As suggested by Ohara (2009), more Japanese companies are becoming multinational due to the global supply chain's advancement. Because of the differences in cultures, customs, and languages in the international arena, it is essential to target the complex context of business models and adjust these to the local business practices to improve business operations.

\section{Conclusion}

The purpose of this work has been to demonstrate the importance of national culture in organizational culture change. The bibliographic research and the research carried out with people involved in the process of organizational change in the JMAM, indicated that the JMAM-FMAM initial idea of synergy failed, due to the lack of consideration of the national identity of the JMAM in its home country. As a result, the JMAM deviated from the local market's business practices, which led to several conflicts within the Alliance. For a competition and individualistic model to work in a country like Japan, ruled by Confucian values, a cultural revolution would be required. Thus, any organizational culture change should be formed in harmony with the country's values. Strictly speaking, organizational cultures that are not aligned with the national culture are doomed to fail in the long run because the latter is the former's cradle. Therefore, when tailoring international projects, project managers should incorporate cultural aspects at the core of their strategies. Strategy strength results from elaborated and logical thinking and requires a careful analysis of the competitive strategy in the context of its operating environment, considering such human and cultural factors for a broader sense of understanding.

Author Contributions: Conceptualization: Lopes, I.H.S.L.; Boyadjian, J.C. Data acquisition: Lopes, I.H.S.L.; Boyadjian, J.C. Data analysis: Lopes, I.H.S.L.; Boyadjian, J.C. Design of methodology: Lopes, I.H.S.L.; Boyadjian, J.C. Writing and editing: Lopes, I.H.S.L.; Boyadjian, J.C.

How to cite: Lopes, I.; Boyadjian, J.C. 2021. Impact of national culture in projects involving organizational culture change: Japonese Business Practices. Quaestum, 2: e26750575.

\section{References}

Abyad, A. 2017. Globalization challenges in project management. Middle East Journal of Business, 12(4): 10-19. Aoki, K.; Lennerfors,T.T. 2013. The New, Improved Keiretsu. Harvard Business Review, 91(9): 109-113.

Barría, C. 2020. Los 3 pilares del "capitalismo sabio" de las empresas japonesas (y cómo contrasta con el "capitalismo de Wall Street”). BBC News Mundo. Available at: <https://www.bbc.com/mundo/noticias-53273712>. Accessed: sep. 21, 2020.

Bowie, N. 1993. International Business, a Universal Morality and the Challenge of Nationalism. p. 95-114. In: Dunfee T.W.; Nagayasu Y. (Eds.). Business Ethics: Japan and the Global Economy. v. 5. Springer, Dordrecht, Netherlands.

Business Culture (BC). 2019. Business communication in France. Available at: <https://businessculture.org/ western-europe/business-culture-in-france/business-communication-in-france/>. Accessed: 29 sep 2020.

Cameron, K.S.; Quinn, R.E. 2011. Diagnosing and Changing Organizational Culture: Based on the Competing Values Framework. 3rd ed - Revised ed. Jossey-Bass. San Francisco, CA, USA.

Dunfee, T.W.; Nagayasu, Y. 1993. Global Business Ethics and Japanese Economic Morality. p 3-22, In: Dunfee T.W., Nagayasu Y. (Eds.). Business Ethics: Japan and the Global Economy, v. 5. Springer, Dordrecht, Netherlands.

Fujimoto, H. 2019. After Ghosn, Nissan's 'keiretsu' suppliers back in the hot seat. Nikkei Asia. Available in: $<$ https://asia.nikkei.com/Business/Companies/After-Ghosn-Nissan-s-keiretsu-suppliers-back-in-the-hotseat>. Accessed: sep. 21, 2020.

Ghosn, C.; Riès, P.; Cullen, J. 2005. Shift: inside Nissan’s historic revival. Doubleday. New York, NY, USA.

Imaguchi, T. 2009. Innovative Strategy and Project Organization. (p. 61-70). In: Ohara S.; Asada, T. Japanese Project Management KPM - Innovation, Development and Improvement. World Scientific Publishing Company, Singapure.

Kinoshita, T. 2009. Changes of Japanese Corporate Business Model under Global Pressure: Evidence Justifying KPM. (p. 83-104). In Ohara, S.; Asada, T. Japanese Project Management KPM - Innovation, Development and Improvement World Scientific Publishing Company, Singapore.

Kobayashi, S. 1993. Business Ethics and Corporate Strategy in Japan. p. 209-216. In: Dunfee T.W., Nagayasu Y. (Eds.). Business Ethics: Japan and the Global Economy, v. 5. Springer, Dordrecht, Netherlands.

Motak, D. 2009. Postmodern spirituality and the culture of individualism. Scripta Instituti Donneriani Aboensis, 21: $149-161$.

Nagayasu, Y. 1993. Globalization and Business Values in the Asian-Pacific Region, p. 81-94. In: Dunfee T.W., Nagayasu Y. (Eds.). Business Ethics: Japan and the Global Economy, v. 5. Springer, Dordrecht, Netherlands.

Naito,T.; Gielen, U. 1992 Tatemae and Honne: A Study of moral relativism in Japanese culture. p. 161-172.In Gielen, U.P.; Adler, L.L.; Milgram, N. (Eds.). Psychology in international perspective. Swets and Zeitlinger: Amsterdam, Netherlands.

Nayebpour, M.; Saito, A. 2007. Toyota vs. Nissan - A contrast in culture, corporate governance, operational strategy, and financial performance. Business Administration theses. Keller Graduate School of Management, 
Houston, Texas, United States. Available in: https://www.researchgate.net/publication/238112455_TOYOTA VS_NISSAN_-_A_CONTRAST_IN_CULTURE_CORPORATE_GOVERNANCE_OPERATIONAL_STRATEGGYAND_ FINANCIAL PERFORMANCE> Accessed: sep. 21, 2020.

Nissan Motor Corporation (NMC). 2002. Nissan Annual Report 2001. Nissan Global. Available in: <https://www. nissan-global.com/EN/DOCUMENT/PDF/AR/2001/ar2001.pdf>. Accessed: sep. 21, 2020.

Nissan Motor Corporation (NMC). 2003. Renault-Nissan Alliance Basics, Available in: <https://www.nissan-global. com/PDF/ALLIANCE/2003/fy03alliance_02_en.pdf. Accessed: oct. 17, 2020.

Nissan Motor Corporation (NMC). 2018. Renault-Nissan-Mitsubishi sells 10.6 million vehicles in 2017. Available in: <https://global.nissannews.com/en/releases/180130-02-e? source=nng \&lang=en-US\#: :text=Groupe\%20 Renault's\%20sales\%20were,Europe\%2C\%20and\%20also\%20for\%20Dacia.>. Accessed: oct 17, 2020.

Odawara, K. 1993. Business Ethics in the Global Age. p.173-188. In: Dunfee T.W.; Nagayasu, Y. Business Ethics: Japan and the Global Economy, v. 5. Springer, Dordrecht, Netherlands.

Ohara, S. 2009. Preface. p. 5-23. In: Ohara, S.; Asada, T. Japanese Project Management KPM Innovation, Development and Improvement. World Scientific Publishing Company, Singapore.

Ohara, S.; Asada, T. 2009. Japanese Project Management: KPM - Innovation, Development and Improvement. 3ed. World Scientific Publishing Company, Singapore.

Porter, S. 2018. Car industry: Who's the biggest of them all? BBC News. Available in: <https://www.bbc.com/news/ business-43028005>. Accessed: oct. 20, 2020.

Project Management Institute (PMI). 2017. A guide to the project management body of knowledge (PMBOK ${ }^{\circledR}$ guide). 6ed. Project Management Institute. Newtown Square, PA, USA.

Shirouzu, N. 1999. Nissan's Restructuring Plan May Hurt Keiretsu System. The Wall Street Journal. Available in: <https://www.wsj.com/articles/SB940353514227686697> Accessed: sep. 21, 2020.

Susini, J. 2004. The Determinants of Alliance Performance: Case Study of Renault \& Nissan Alliance. Econ. J. Hokkaido Univ, 33: 232-262.

Taka, I. 1993. Business Ethics: A Japanese view. p.23-62. In Dunfee T.W. and Nagayasu, Y. Business Ethics: Japan and the Global Economy, v. 5. Springer, Dordrecht, Netherlands.

Takeuchi, H. 2013. Wise Leadership and Wise Capitalism. Kindai Management Review 1: 15-26.

Thiry, M. 2009. A comparison between three leading program management standards. paper presented at PMI ${ }^{\circledR}$ Global Congress 2009-Asia Pacific, Kuala Lumpur, Malaysia. Newtown Square, PA, USA.

Toyota Motor Corporation (TMC). 2012. Section 7: The Functions that Supported Globalization - Item 1. A Wave of Restructuring and a Push for Change in Awareness: Promotion of collaboration with Japanese automakers. Available in: <https://www.toyota-global.com/company/history_of_toyota/75years/text/leaping_forward_as_a_ global_corporation/chapter4/section7/item1.html>. Accessed: sep. 21, 2020.

Trompenaars, A.; Hampden-Turner, C. 1993. Riding the waves of culture: understanding diversity in global business. 2thed. Nicholas Brealey Publishing. London, UK.

Tucker, J. 2018. Japanese Confucian Philosophy. The Stanford Encyclopedia of Philosophy (Spring 2018 Edition), Zalta, N.Z. (Ed.). Available in: <https://plato.stanford.edu/archives/spr2018/entries/japanese-confucian/>. Accessed: sep. 21, 2020.

Twomey, B. 2020. Understanding Japanese Keiretsu. Investopedia, LLC. New York, NY, USA. Available in: <https:// www.investopedia.com/articles/economics/09/japanese-keiretsu.asp>. Accessed: sep. 21, 2020.

World Population Review (WPR). 2020. Most Technologically Advanced Countries 2020. Available in: <https:// worldpopulationreview.com/country-rankings/most-technologically-advanced-countries >. Accessed at: 26 sep. 2020.

Yin, R.K. 2009. Case study research: Design and methods. 4ed. Sage Publications, Inc. Thousand Oaks, CA, USA.

Yui, T. 1993. Economic development and ethic in Japan. - A Historical Perspective. p. 255-275. In: Dunfee T.W.; Nagayasu, Y. Business Ethics: Japan and the Global Economy, v. 5. Springer, Dordrecht, Netherlands. 